\title{
Inhibitory effect of topical Adelmidrol on antigen-induced skin wheal and mast cell behavior in a canine model of allergic dermatitis
}

\author{
Santiago Cerrato ${ }^{1,3}$, Pilar Brazis ${ }^{1}$, Maria Federica della Valle ${ }^{2}$, Alda Miolo ${ }^{2}$ and Anna Puigdemont ${ }^{3^{*}}$
}

\begin{abstract}
Background: Adelmidrol is a semisynthetic derivative of azelaic acid and analogue of the anti-inflammatory compound palmitoylethanolamide (PEA). Based upon its physicochemical properties, adelmidrol is suitable for topical application. The main objective of the present study was to evaluate the efficacy of a topical adelmidrol emulsion on early and late inflammatory responses in hypersensitive dogs. Repeated intradermal injections of Ascaris suum extract were performed in both lateral thoracic areas of six conscious hypersensitive Beagle dogs, topically treated during 8 consecutive days. Adelmidrol (2\%) was applied to one side and vehicle to the other. 24 hours after the last antigen challenge, two biopsies (adelmidrol- and vehicle-treated side) were obtained for each dog at the antigen injection site.
\end{abstract}

Results: A significant reduction in the antigen-induced wheal areas was observed on the $4^{\text {th }}$ and $7^{\text {th }}$ day of adelmidrol treatment. Moreover, cutaneous mast cell numbers were significantly decreased in biopsies obtained after 8 consecutive days of topical adelmidrol treatment.

Conclusions: The results obtained in the present study show that topical treatment with adelmidrol might represent a new therapeutic tool in controlling the early and late allergic inflammatory skin responses in companion animals.

Keywords: Adelmidrol, Aliamides, Mast cells, Allergy, Ascaris suum, Dogs

\section{Background}

Adelmidrol is the diethanolamide derivative of azelaic acid, i.e., naturally occurring dicarboxylic acid that has long proven to be an effective topical treatment for human inflammatory skin disorders [1], and whose mechanism of action has been extensively investigated [2]. Similar to the anti-inflammatory and antinociceptive compound palmitoylethanolamide (PEA) [3-12], adelmidrol belongs to the aliamide family [13,14], a group of fatty acid derivatives with cannabimimetic properties, able to control mast cell (MC) hyperreactivity in several pathophysiological and pathological conditions [5,8,15-17]. We have recently found that PEA down-modulates the release of both preformed and newly-synthesized mediators from canine skin MCs

\footnotetext{
* Correspondence: anna.puigdemont@uab.es

${ }^{3}$ Departament de Farmacología, Facultat de Veterinària, Universitat

Autònoma de Barcelona, 08193, Bellaterra, Barcelona, Spain

Full list of author information is available at the end of the article
}

challenged with immunologic stimuli [18]. Moreover, the PEA analogue adelmidrol has been shown to negatively control the behavior of canine skin MCs during pathophysiological conditions (i.e. healing of experimental wounds) [19]. In particular, a statistically significant increase of intracytoplasmic granular content of dermal MCs was shown in adelmidrol (2\%)-treated wounds compared to control, thus suggesting the compound is effectively able to down-modulate skin MC degranulation in dogs [19]. Furthermore, the local application of adelmidrol confirmed the reduction in $\mathrm{MC}$ responses during chronic experimental inflammation, as shown by the significant decrease of mediators such as chymase which are selectively expressed by MCs and intimately involved in skin inflammation [20].

Mast cell hyperactivity is involved in the pathobiology of several canine disorders [21-23], including those of a dermatological nature $[24,25]$. In a canine model of allergic dermatitis, i.e., spontaneous hypersensitivity to the 
parasite Ascaris suum, the intradermal antigen exposure triggers the immediate degranulation of MCs, resulting in an early phase reaction (EPR), clinically manifested as skin wheals [24,26-30]. The combined actions of newlysynthesized and preformed mediators released by MCs results in the subsequent transcription of inflammatory cytokines and chemokines that ultimately drive the recruitment of inflammatory cells to the site of antigen injection. This process is known as the late phase reaction (LPR) and can become chronic [31,32]. We have recently found that a single oral dose of PEA $(10 \mathrm{mg} / \mathrm{kg})$ reduced significantly the antigen-induced skin wheal reaction in hypersensitive Beagle dogs [33]. Moreover, the repeated administration of PEA (5 and $10 \mathrm{mg} / \mathrm{kg}$, intraperitoneal) has been shown to play a protective role against inflammation in experimental allergic dermatitis [34]. Unlike PEA, which is a highly lipophilic compound, adelmidrol is more suited to topical application, because exhibits both hydrophilic and lipophilic features (i.e,. amphipathic properties), which facilitates its absorbtion into the skin, whose epidermis is composed of alternating lipophilic and hydrophilic layers. A 4-week topical treatment with adelmidrol $2 \%$ emulsion in children affected by mild atopic dermatitis resulted in complete resolution in $80 \%$ of cases, with no side effects and no relapses at 8-week follow up [35]. In the last decades, the use of topical therapy in veterinary dermatology has increased and is especially recommended for localized allergic skin lesions, where it is currently regarded as a sole therapy or an adjunctive therapy minimizing the need for systemic treatments [36,37]. Based on the aforementioned background, the aim of the present study was to investigate whether, similar to PEA [33], adelmidrol was able to limit the inflammatory allergic response upon topical application.

\section{Methods}

Drugs, chemicals, and reagents

Adelmidrol (2\%) and vehicle emulsions were purchased by Innovet (Milano, Italy). A. suum extract was purchased from Greer Laboratories (Lenoir, NC, United States). Evans blue dye and histamine diphosphate salt were obtained from Sigma-Aldrich (St. Louis, MD, United States).

\section{Animals}

Six spontaneously hypersensitive Beagle dogs (four females and two males) with mean body weights of 15.2 $\pm 0.7 \mathrm{~kg}$ were used in this study. No drugs or additional treatments were given during the study, except sedatives, administered prior to obtaining the biopsies. All experiments and procedures were performed in accordance with European regulations governing the care and treatment of laboratory animals and were approved by the
Animal Care and Use Committee of the Universitat Autònoma de Barcelona.

\section{Experimental protocol}

The method used was based on measurement of the inhibition of the wheal area induced, in the right and left shaved lateral thoracic areas $\left(25 \mathrm{~cm}^{2}\right.$ per area) of dogs, by intradermal injections of an $A$. suum extract solution $(0.01 \% \mathrm{w} / \mathrm{v})$, before and after treatments. Topical solutions $(4 \mathrm{ml})$ of adelmidrol $2 \%$ and vehicle were applied three times a day for 8 consecutive days in the injected areas. In order to better visualize wheal areas, a $2 \% \mathrm{w} / \mathrm{v}$ Evans blue dye solution in saline was given intravenously $(0.4 \mathrm{~mL} / \mathrm{kg}) 30 \mathrm{~min}$ before each antigen injection. Three challenges were performed before (first challenge), on the $4^{\text {th }}$ day (second challenge) and the $7^{\text {th }}$ day (third challenge) of treatment, using a Hamilton syringe (type 701LT) (Reno, NV, United States). The results from the first challenge (i.e., performed prior to treatment) were taken as the baseline response. Each intradermal antigen challenge was performed 10 minutes before the second daily treatment application (Figure 1). Histamine $(0.001 \% \mathrm{w} / \mathrm{v})$ and saline were also injected, as positive and negative controls, respectively.

\section{Planimetry}

10 minutes after intradermal challenge with $A$. suum extract solution, wheal areas were traced on an acetate sheet over the reaction site with indelible ink. Areas were then analyzed with an image analyzer MIP 4 ADVANCED (Digital Image System, Barcelona, Spain).

\section{Collection of skin biopsy specimens}

24 hours after the third challenge, dogs received a local anaesthesia consisting of a subcutaneous injection of lidocaine $(2 \%)$ without adrenaline, and two $6-\mathrm{mm}$ punch

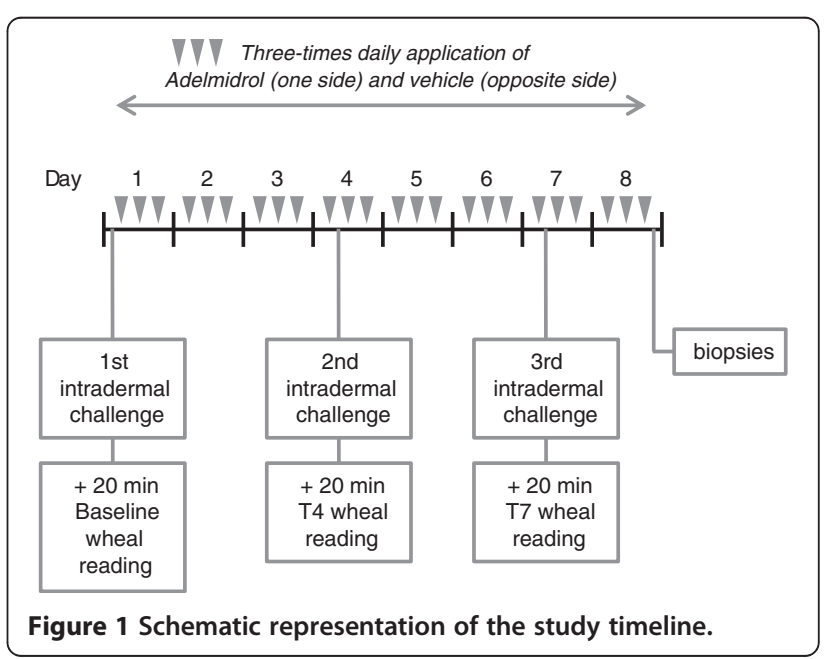


skin biopsies (i.e., adelmidrol- and vehicle-treated side) were collected at injection sites.

\section{Histopathology}

All biopsy specimens were fixed in neutral buffered formalin and embedded in paraffin for routine processing. $5 \mu \mathrm{m}$ sections were stained with haematoxylin-eosin and toluidine blue (to visualize MC metachromatic granules). Dermis oedema and cell recruitment were graded semiquantitatively on an arbitrary scale [i.e., $-/+(0-1$ cell); + $+(1-3$ cells $) ;+++(3-6$ cells $) ;++++(>6$ cells $)]$, on a $x 400$ total magnification microscope. In particular, MC counts (per unit area) were determined on six randomly selected sections for each of the three different dermal layers, identified according to the known vascular plexuses subdivision in the skin, i.e., superficial (just beneath the epidermis), middle (around middle portions of hair follicles and sebaceous glands) and deep dermis (around the inferior portion of hair follicles and dermis/subcutis interface). Histological slides were read blindly with respect to treatment.

\section{Data analysis}

To guarantee test reproducibility all experiments were performed by the same investigator blinded to the animal's treatment. Wheal areas were expressed in $\mathrm{mm}^{2}$ as means \pm standard error of the mean (mean \pm SEM). Response variability in wheal areas was analyzed using the coefficient of variation $(\mathrm{CV})$ before starting the treatments. Results were expressed as the percentage of inhibition observed for each challenge, comparing the antigen wheal area obtained in the same dog in the adelmidroltreated side or vehicle-treated side versus the areas obtained at baseline $\left(t_{0}\right)$. Wheal inhibition was calculated with the following formula,

$$
\% \text { inhibition }=\frac{\mathrm{t}_{\mathrm{n}} \text { area }\left(\mathrm{mm}^{2}\right)-\mathrm{t}_{0} \text { area }\left(\mathrm{mm}^{2}\right)}{\mathrm{t}_{0} \text { area }\left(\mathrm{mm}^{2}\right)} \times 100
$$

where $t_{0}$ area corresponds to baseline value and $t_{n}$ area is the area after adelmidrol or vehicle application, at a given time.

Differences between means were analyzed using an ANOVA test for paired measures and a Tukey's multiple comparison post-hoc test. Statistical significance was set at $P<0.05$ and $P<0.01$.

Differences between MC numbers were compared using the Student's $t$-test for paired data with a level of significance of $P<0.05$ and $P<0.01$.

Compliance with conditions for applying the aforementioned tests was verified with the KolmogorovSmirnov normality test.

\section{Results}

\section{Macroscopic findings}

In order to assess the repeatability of wheal area measure over time, wheal areas induced by subsequent $A$. suum extract injections in each dog were studied. Despite the differences observed between dogs (CV $>10 \%)$, no within-dog differences were observed $(\mathrm{CV}<5 \%)$. For this reason, the adelmidrol inhibitory effect in each dog was calculated from its own basal value.

Figure 2 shows the mean inhibition percentage of wheal areas induced in hypersensitive Beagle $\operatorname{dogs}$ by $A$. suum extract before and after 3 and 6 consecutive days of topical treatment with adelmidrol or vehicle, in comparison with baseline wheal areas. After 3 and 6 days of topical adelmidrol treatment, a statistically significant reduction in wheal areas was observed $(P=0.001$ and $P=$ $0.003)$, reaching an inhibition of $19.9 \pm 2.5$ and $36.8 \pm$ $3.5 \%$, respectively. The difference between the adelmidrol inhibitory effect observed on day 4 and 7 was statistically significant $(P=0.025)$. Conversely, the vehicle did not exert any significant effect on the wheal formation at any time $(P=0.054$ and $P=0.3$, at the two observation times respectively) (Figure 2 ).

\section{Microscopic findings}

24 hours after the third intradermal allergen challenge (i.e., 8 days after starting treatment) a skin biopsy from each treatment side was obtained and the inflammatory reaction was histologically evaluated. The analysis revealed that oedema was evident within the vehicletreated area in all six cases, while only two out of six dogs presented oedema in the adelmidrol-treated side. Furthermore, in the adelmidrol-treated side a slight, albeit not statistically significant, reduction in the recruitment of eosinophils, lymphocytes, monocytes and

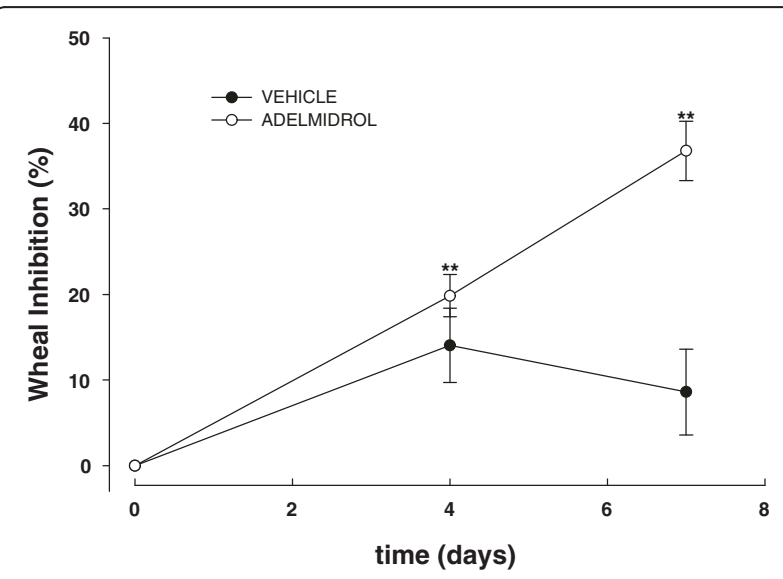

Figure 2 Mean inhibition percentage $( \pm \operatorname{SEM})(n=6)$ of wheal areas induced in conscious hypersensitive Beagle dogs by $A$. suum extract observed before, on the $4^{\text {th }}$ and $7^{\text {th }}$ day of treatment with adelmidrol $2 \%$ or vehicle. ${ }^{* *} P<0.01$. 
neutrophils was observed compared to the vehicletreated side. Mast cell numbers decreased in almost all biopsies after treatment and for this reason a more accurate quantification was performed.

Using toluidine blue staining for dermal MC counts, a highly significant reduction was observed in the adelmidrol-treated side $(P=0.0003)$ (Figure 3). Quantitative evaluation of MCs in the three different dermal layers that were studied (i.e., superficial, middle and deep dermis) revealed a significant decrease in MC numbers in the adelmidrol-treated side compared to the vehicletreated side (Table 1).

\section{Discussion}

The present study shows, for the first time, that adelmidrol effects are evident in both the EPR and LPR in spontaneous hypersensitive Beagle dogs after intradermal antigen challenge. Topical treatment with adelmidrol (2\%) for 3 and 6 consecutive days resulted in a significantly reduced skin wheal response compared to baseline values. Conversely, the vehicle-treated side did not show any significant wheal reduction at any treatment time, thus confirming, albeit indirectly, the lack of systemic absorption of adelmidrol after topical application.

\section{Magnitude of the inhibitory effect on skin wheal}

Adelmidrol topical application inhibited wheal formation by about 20 and 37\%, after 3 and 6 days of treatment, respectively. Results were of about the same magnitude as those observed in a previous study performed with a single oral dose of the aliamide parent molecule PEA in hypersensitive Beagle dogs [33]. The administration of PEA before intradermal antigen challenge resulted in a significant 29 and $32 \%$ reduction in wheal area, respectively, with doses of 10 and $30 \mathrm{mg} / \mathrm{Kg}$ [33].

A number of studies on the inhibitory effects of different drugs on skin wheal response in dogs have been published. The key findings are summarized in Table 2.
Table 1 Quantification of mast cells (3 fields of 400X) in biopsies collected after topical vehicle and $2 \%$ adelmidrol treatment

MAST CELL NUMBER OBSERVED AFTER VEHICLE AND ADELMIDROL TREATMENT

\begin{tabular}{|c|c|c|c|}
\hline \multirow{2}{*}{$\begin{array}{l}\text { Investigated } \\
\text { dermal layer }\end{array}$} & ADELMIDROL & VEHICLE & \multirow[t]{2}{*}{ P-VALUE } \\
\hline & $($ MEAN \pm SEM) & $(\mathrm{MEAN} \pm \mathrm{SEM})$ & \\
\hline Superficial & $3.8 \pm 0.6$ & $6.6 \pm 1.1$ & 0.03 \\
\hline Middle & $1.1 \pm 0.3$ & $2.9 \pm 0.6$ & 0.02 \\
\hline Deep & $0.4 \pm 0.2$ & $1.3 \pm 0.3$ & 0.01 \\
\hline
\end{tabular}

The effect of corticosteroids (both oral or topical) on intradermally-induced skin wheal ranges from lack of effect $[38,39]$ up to $45 \%$ inhibition [40-43], with the only exception of one single study ( $72 \%$ inhibition rate) [44]. Interestingly, similar results are observed in allergic human patients (i.e., $30-40 \%$ inhibition) [45], and better outcomes are known to occur with longer treatment [46]. The inhibitory effect of oral antihistamines on antigen-induced skin wheal in dogs is on average 50\% $[27,43]$, with obviously better results with histamine challenge [47,48] (Table 2). Interestingly, topically applied sodium cromoglycate (i.e., a MC stabilizer agent) inhibits the skin wheal in atopic human patients by only $27 \%$ [49].

On the whole, one may consider wheal inhibition by topically applied adelmidrol to be almost the same order of magnitude as that of topical corticosteroids and lower than the value achieved after oral administration of antihistamines, whose clinical validity and utility remain doubtful [37]. Moreover, similarly to corticosteroids, treatment time could be a crucial factor [46] and longer treatment with topical adelmidrol (i.e., over 7 days) could increase the effect size.

\section{The purported mechanism involves mast cell control}

Mast cells are considered to be major players of EPR [50-52]. Within minutes of antigen exposure, they

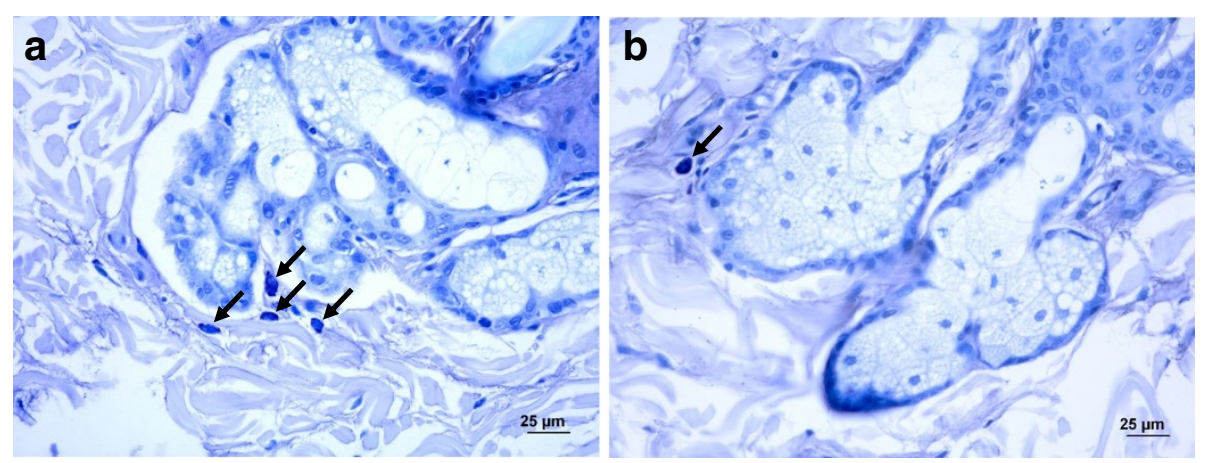

Figure 3 Mast cells obtained from Beagle skin biopsies after toluidine blue staining (black arrows). Histological sections from the vehicletreated side (a) and adelmidrol-treated side (b). 
Table 2 Main studies on the inhibition of skin wheal response in dogs - key findings

\begin{tabular}{|c|c|c|c|c|c|c|}
\hline Subjects & $\begin{array}{l}\text { Intradermal } \\
\text { challenge }\end{array}$ & Drug & $\begin{array}{l}\text { Administration } \\
\text { route }\end{array}$ & $\begin{array}{l}\text { Treatment } \\
\text { time }\end{array}$ & $\begin{array}{c}\text { Wheal inhibition vs } \\
\text { baseline }\end{array}$ & Ref \\
\hline Healthy Beagle dogs & Anti-canine lgE & Corticosteroids (prednisolone) & Oral & $\begin{array}{l}\text { Twice daily } \\
\text { for } 3 \text { days }\end{array}$ & No effect & {$[38]$} \\
\hline $\begin{array}{l}\text { Dogs with pruritic } \\
\text { dermatitis }\end{array}$ & $\begin{array}{l}\text { Histamine (5 } \\
\text { different } \\
\text { dilutions) }\end{array}$ & $\begin{array}{c}\text { Corticosteroids (hydrocortisone } \\
1 \% \text { ) }\end{array}$ & $\begin{array}{c}\text { Topical } \\
\text { (conditioner) }\end{array}$ & $\begin{array}{l}\text { Twice weekly } \\
\text { for } 6 \text { weeks }\end{array}$ & No effect & [39] \\
\hline Healthy Beagle dogs & Histamine & Corticosteroids (betamethasone) & $\begin{array}{l}\text { Topical (otic } \\
\text { preparation) }\end{array}$ & $\begin{array}{l}\text { Twice daily } \\
\text { for } 2 \text { weeks }\end{array}$ & $5.9 \%$ & {$[40]$} \\
\hline Healthy Beagle dogs & D. farinae & Corticosteroids (betamethasone) & $\begin{array}{l}\text { Topical (otic } \\
\text { preparation) }\end{array}$ & $\begin{array}{l}\text { Twice daily } \\
\text { for } 2 \text { weeks }\end{array}$ & $9 \%$ & {$[40]$} \\
\hline Healthy Beagle dogs & $\begin{array}{l}\text { Cynodon } \\
\text { dactylon }\end{array}$ & Corticosteroids (betamethasone) & $\begin{array}{l}\text { Topical (otic } \\
\text { preparation) }\end{array}$ & $\begin{array}{l}\text { Twice daily } \\
\text { for } 2 \text { weeks }\end{array}$ & $9.8 \%$ & {$[40]$} \\
\hline Healthy Beagle dogs & Anti-canine lgE & $\begin{array}{c}\text { Corticosteroids (hydrocortisone } \\
1 \% \text { ) }\end{array}$ & $\begin{array}{c}\text { Topical } \\
\text { (conditioner) }\end{array}$ & 3 days & $14 \%(*)$ & {$[41]$} \\
\hline Healthy dogs & $\begin{array}{c}\text { Anti-canine lgE } \\
\text { (different } \\
\text { dilutions) } \\
\end{array}$ & Corticosteroids (triamcinolone) & $\begin{array}{l}\text { Topical } \\
\text { (solution) }\end{array}$ & 7 days & $\begin{array}{l}24-45 \%(\S) \text { depending on } \\
\text { the stimulus concentration }\end{array}$ & {$[42]$} \\
\hline $\begin{array}{l}\text { Healthy mixed breed } \\
\text { dogs }\end{array}$ & D. farinae & Corticosteroids (prednisone) & Oral & 7 days & $41 \%$ & {$[43]$} \\
\hline $\begin{array}{l}\text { Atopic Maltese-beagle } \\
\text { cross-breed dogs }\end{array}$ & Anti-canine lgE & $\begin{array}{c}\text { Corticosteroids (hydrocortisone } \\
\text { aceponate) }\end{array}$ & Topical (spray) & 7 days & $72 \%$ & {$[44]$} \\
\hline $\begin{array}{l}\text { Healthy mixed breed } \\
\text { dogs }\end{array}$ & D. farinae & Antihistamines (cetrizine) & Oral & 14 days & $49 \%$ & {$[43]$} \\
\hline $\begin{array}{l}\text { Spontaneously Ascaris } \\
\text { hypersensitive Beagle } \\
\text { dogs }\end{array}$ & A. suum & Antihistamines (rupatadine) & Oral & $\begin{array}{l}\text { Single pre- } \\
\text { treatment } \\
\text { dose }\end{array}$ & 35,67 and $84 \%(\#)$ & {$[27]$} \\
\hline $\begin{array}{l}\text { Spontaneously Ascaris } \\
\text { hypersensitive Beagle } \\
\text { dogs }\end{array}$ & A. suum & Antihistamines (loratadine) & Oral & $\begin{array}{c}\text { Single pre- } \\
\text { treatment } \\
\text { dose }\end{array}$ & 34,61 and $66 \%$ (\#) & {$[27]$} \\
\hline Healthy Beagle dogs & PAF & Antihistamines (rupatadine) & Oral & $\begin{array}{c}\text { Single pre- } \\
\text { treatment } \\
\text { dose }\end{array}$ & $30 \%$ to $45 \%(¥)$ & {$[47]$} \\
\hline Healthy Beagle dogs & Histamine & Antihistamines (rupatadine) & Oral & $\begin{array}{l}\text { Single pre- } \\
\text { treatment } \\
\text { dose }\end{array}$ & $50 \%$ to $80 \%(¥)$ & {$[47]$} \\
\hline Healthy Beagle dogs & Histamine & $\begin{array}{c}\text { Antihistamines (cetrizine, } \\
\text { loratadine, rupatadine, } \\
\text { levocabastine) }\end{array}$ & Oral & $\begin{array}{l}\text { Single pre- } \\
\text { treatment } \\
\text { dose }\end{array}$ & $70 \%$ to $80 \%\left({ }^{* *}\right)$ & {$[48]$} \\
\hline Healthy Beagle dogs & Histamine & $\begin{array}{l}\text { Antihistamines (cetrizine, } \\
\text { loratadine, rupatadine, } \\
\text { levocabastine) }\end{array}$ & Oral & $\begin{array}{l}\text { Single pre- } \\
\text { treatment } \\
\text { dose }\end{array}$ & $70 \%$ to $80 \%(* *)$ & {$[48]$} \\
\hline
\end{tabular}

$(*)$ versus placebo group;

(§) versus vehicle-treated side;

(\#) peak activity at $0.1,1$ and $10 \mathrm{mg} / \mathrm{Kg}$ respectively, 2 to $4 \mathrm{hrs}$ after administration;

(¥) peak activity, $4 \mathrm{~h}$ after administration, depending on the dose;

$\left.{ }^{* *}\right)$ peak activity, $4 \mathrm{~h}$ after administration, depending on the compound and the dose

rapidly secrete performed mediators (e.g., histamine, tryptase, chymase) and membrane-derived eicosanoids leading to the so-called 'wheal and flare' reaction of the skin [53,54]. The ability of aliamides (to whose family the tested compound belongs) to down-modulate the release of bioactive mediators from MCs [18-20] may thus represent the mechanism of the inhibitory effect on wheal areas, observed in the present study. Indeed, adelmidrol can down-modulate skin MC degranulation both during pathophysiological canine conditions [19] and in experimental chronic inflammation [20]. Moreover, the significant increase in the percentage inhibition of wheal area observed from the $4^{\text {th }}$ to $7^{\text {th }}$ day of treatment (from about 20 to $37 \%$ inhibition) may depend on the purported mechanism of action of the compound, i.e. the down-modulation of hyperactive skin MCs $[19,20]$, which represents an endogenous tuning mechanism and thus a gradual, progressive phenomenon - rather than an immediate 'pharmacological' switch-off effect [55].

The present study also demonstrates the inhibitory effect of adelmidrol on the increased MC number observed 
$24 \mathrm{~h}$ after the last antigen challenge (corresponding to the end of the 8-day-treatment). Indeed, the adelmidroltreated side showed $42 \%, 62 \%$ and $69 \%$ less MCs in the superficial, middle and deep dermis respectively, compared to the vehicle-treated side. Although the baseline data are missing (the study was not designed to have $\mathrm{t} 0 \mathrm{bi}$ opsies), this finding suggests that adelmidrol limited the LPR by decreasing skin MC hyperplasia following antigen challenge. Thus, both the functional and quantitative control of MCs might explain the observed anti-allergic effect of the topical treatment with adelmidrol. Indeed, similar findings emerged from a study on a model of chronic inflammation, where the local administration of adelmidrol both down-modulated $\mathrm{MC}$ degranulation and prevented numerical increase of MC numbers [20]. Interestingly, topical corticosteroids decrease MC numbers in humans [56], without any apparent effect on dogs [44].

Whether the effect on MC number observed in the present study depends on the inhibition of MC proliferation or maturation from progenitors, both resident and recruited from circulation, could not be tested by the techniques used in here. Both hypotheses may be possible, since the adelmidrol analogue PEA has been shown to (i) down-modulate keratinocyte production of the inflammatory cytokines [34], responsible for the recruitment of MCs [57]; and (ii) limit MC release of nerve growth factor [16], a neurotrophin that promotes chemotaxis of MCs as well as their maturation and degranulation [55,58,59]. Moreover, a recent study has shown the existence of an inhibitory "endocannabinoid tone" of skin MC biology, with skin MCs utilizing endocannabinoid signaling to limit not only their own activation/degranulation but also their maturation from resident progenitor cells [60]. This finding is particularly interesting since aliamides share several aspects of their biochemistry, metabolism and pharmacology with endocannabinoids and have been referred to as endocannabinoid-like, cannabimimetic compounds, or even indirect endocannabinoids [61,62]. Moreover, endocannabinoid receptors (i.e., $\mathrm{CB} 1$ and $\mathrm{CB} 2$ ) have been discovered in the canine skin and found to increase in diseased conditions, such as atopic dermatitis [63]. Finally, one should also consider that adelmidrol is a lipid amide and epidermal cells express the respective degrading enzymes (e.g., fatty acid amide hydrolase) [64]. Thus topically applied adelmidrol can be partially cleaved to release azelaic acid, which in turn might contribute to the observed effect, lessening the inflammatory phenotype of keratinocytes [2]. Importantly, no sign of irritation or any adverse effect was noticed during the present study.

\section{Practical considerations}

From a practical point of view, the present findings suggest that adelmidrol could find a place in the management of hypersensitive skin disorders in the dog, where topical treatments are currently preferred to systemic ones for localized lesions characterizing the less severe stages of the disease. Alternatively, adelmidrol could be applied as an adjunct to systemic treatments for a "dual-site action" in selected cases, as suggested for more classical topical tools [37]. The most frequently used topical treatments for canine allergic skin diseases are glucocorticoid formulations and tacrolimus oinment. Both approaches are effective, even though tacrolimus has a slow onset of action, and both exert adverse effects (i.e., mild irritation, cutaneous atrophy, superficial follicular cysts, and increased susceptibility to skin infection) that, although mild, can prejudice owner compliance and lengthen recovery [37].

\section{Conclusions}

Intradermal injection of allergic-inflammatory stimuli, with measurement of immediate wheal reaction and later dermal cellular infiltrates has been considered a useful technique for objectively documenting the antiinflammatory effect of topical preparations in dogs [42]. The present study evaluated the effect of the topical daily application of the aliamide adelmidrol on the canine skin response to intradermal allergen challenge and confirmed its anti-inflammatory effect. In particular, the tested aliamide significantly reduced both EPR and LPR in hypersensitive dogs. A significant decrease in acute inflammation response and MC numbers was observed, without any sign of irritation or adverse effect. Even though further and more detailed molecular studies are needed to confirm the results and broaden knowledge on the mechanisms involved, the present findings suggest that adelmidrol emulsion could represent a valuable and safe tool in the armamentarium for canine inflammatory allergic skin disorders. The effects on wheal and MC numbers provide a sound basis for an antiinflammatory drug sparing effect, and predict adelmidrol to be profitably combined with oral treatments for an optimal dual site therapy, i.e. outside-inside approach, currently the most preferred route for managing canine hypersensitive skin disorders [37].

\section{Competing interests}

Alda Miolo is an employee of CeDIS (Science Information and Documentation Centre), Innovet Italia srl. Maria Federica della Valle is a scientific consultant for the same company. None of the other authors declare a conflict of interest.

\section{Authors' contributions}

SC and AP carried out the experiments and analyzed the data. AM and MFdV participated in the design of the study and helped to draft the manuscript. AP and PB conceived of the study, and participated in its design and coordination and helped to draft the manuscript. All authors read and approved the final manuscript.

\section{Acknowledgements}

This work was supported by Innovet Italia srl. The Authors are grateful to Dr Stephen D. Skaper (Dipartimento di Scienze del Farmaco, Università degli 
Studi di Padova) for his valuable help in English-language editing, critical comments and greatly appreciated scientific advice.

\section{Author details}

${ }^{1}$ UNIVET, Edificio Astrolabio, Avinguda Cerdanyola 92, 08172 Sant Cugat del Vallès, Barcelona, Spain. ${ }^{2}$ Cedis, INNOVET Italia, Via Egadi 7, 20144, Milan, Italy. ${ }^{3}$ Departament de Farmacología, Facultat de Veterinària, Universitat Autònoma de Barcelona, 08193, Bellaterra, Barcelona, Spain.

Received: 1 June 2012 Accepted: 4 November 2012

Published: 26 November 2012

\section{References}

1. Nazzaro-Porro M: Azelaic acid. J Am Acad Dermatol 1987, 17:1033-1041.

2. Mastrofrancesco A, Ottaviani M, Aspite N, Cardinali G, Izzo E, Graupe K, Zouboulis CC, Camera E, Picardo M: Azelaic acid modulates the inflammatory response in normal human keratinocytes through PPARgamma activation. Exp Dermatol 2010, 19:813-820.

3. Costa B, Comelli F, Bettoni I, Colleoni MP, Giagnoni G: The endogenous fatty acid amide, palmitoylethanolamide, has anti-allodynic and antihyperalgesic effects in a murine model of neuropathic pain: involvement of CB1, TRPV1 and PPARgamma receptors and neurotrophic factors. Pain 2008, 139:541-550.

4. Lo Verme J, Fu J, Astarita G, La Rana G, Russo R, Calignano A, Piomelli D: The nuclear receptor peroxisome proliferator-activated receptor-alpha mediates the anti-inflammatory actions of palmitoylethanolamide. $\mathrm{Mol}$ Pharmacol 2005, 67:15-19.

5. Re G, Barbero R, Miolo A, Di Marzo V: Palmitoylethanolamide, endocannabinoids and related cannabimimetic compounds in protection against tissue inflammation and pain: Potential use in companion animals. Vet J 2007, 173:23-32.

6. Wise LE, Cannavacciuolo R, Cravatt BF, Marun BF, Lichtman AH: Evaluation of fatty acid amides in the carrageenan-induced paw edema model. Neuropharmacology 2008, 54:181-188.

7. Genovese T, Esposito E, Mazzon E, Di Paola R, Meli R, Bramanti P, Piomeli D, Calignano A, Cuzzocrea S: Effects of palmitoylethanolamide on signaling pathways implicated in the development of spinal cord injury. J Pharmacol Exp Ther 2008, 326:12-23.

8. De Filippis D, Luongo L, Cipriano M, Palazzo E, Cinelli MP, de Novellis V, Maione $S$, luvone T: Palmitoylethanolamide reduces granuloma-induced hyperalgesia by modulation of mast cell activation in rats. Mol Pain 2011, 7:3.

9. Luongo L, Guida F, Gatta L, de Novellis V, Maione S: Palmitoylethanolamide systemic treatment reduces spinal and supraspinal formalin-induced neuroinflammation and allodynia. Shock 2011, 36(Suppl 1):22.

10. Sasso O, Russo R, Vitiello S, Mattace Raso G, D'Agostino G, lacono A, La Rana G, Vallée M, Cuzzocrea S, Piazza PV, Meli R, Calignano A: Implication of allopregnanolone in the antinociceptive effect of $\mathrm{N}$ palmitoylethanolamide in acute or persistent pain. Pain 2012, 153:33-41.

11. Truini A, Biasiotta A, Di Stefano G, Cesa SL, Leone C, Cartoni C, Federico V, Petrucci MT, Cruccu G: Palmitoylethanolamide restores myelinated-fibre function in patients with chemotherapy-induced painful neuropathy. CNS Neurol Disord Drug Targets 2011, 10:916-920.

12. Keppel Hesselink JM: New targets in pain, non-neuronal cells, and the role of palmitoylethanolamide. Mini-review. Open Pain J 2012, 5:12-23.

13. Aloe $L$, Leon A, Levi-Montalcini R: A proposed autacoid mechanism controlling mastocyte behaviour. Agents Actions 1993, 39(Spec No):C145C147.

14. Jack DB: Aliamides: a new approach to the treatment of inflammation. Drug News Perspect 1996, 9:93-98.

15. De Filippis D, D'Amico A, luvone T: Cannabinomimetic control of mast cell mediator release: new perspective in chronic inflammation. $J$ Neuroendrocrinol 2008, 20(Suppl 1):20-25.

16. Cantarella G, Scollo M, Lempereur L, Saccani-Jotti G, Basile F, Bernardini R: Endocannabinoids inhibit release of nerve growth factor by inflammation-activated mast cells. Biochem Pharmacol 2011, 82:380-388.

17. Esposito E, Paterniti I, Mazzon E, Genovese T, Di Paola R, Galuppo M, Cuzzocrea S: Effects of palmitoylethanolamide on release of mast cell peptidases and neurotrophic factors after spinal cord injury. Brain Behav Immun 2011, 25:1099-1112.
18. Cerrato S, Brazis P, Della Valle MF, Miolo A, Puigdemont A: Effects of palmitoylethanolamide on immunologically induced histamine, $P G D_{2}$ and TNFa release from canine skin mast cells. Vet Immunol Immunopathol 2010, 133:9-15.

19. Abramo F, Salluzzi D, Leotta R, Auxilia S, Noli C, Miolo A, Mantis P, Lloyd DH: Mast cell morphometry and densitometry in experimental skin wounds treated with a Gel containing adelmidrol: a placebo controlled study. Wounds 2008, 20:149-157.

20. De Filippis D, D'Amico A, Cinelli MP, Esposito G, Di Marzo V, luvone T: Adelmidrol, a palmitoyethanolamide analogue, reduces chronic inflammation in a carrageenin-granuloma model in rats. $J$ Cell Mol Med 2009, 13:1086-1095.

21. Su M, Chi EY, Bishop MJ, Henderson WR Jr: Lung mast cells increase in number and degranulate during pulmonary artery occlusion/reperfusion injury in dogs. Am Rev Respir Dis 1993, 147:448-456.

22. Kleinschmidt S, Meneses F, Nolte I, Hewicker-Trautwein M: Distribution of mast cell subtypes and immune cell populations in canine intestines: Evidence for age-related decline in T cells and macrophages and increase of IgA-positive plasma cells. Res Vet Sci 2008, 84:41-48.

23. Woldemeskel M, Rajeev S: Mast cells in canine cutaneous hemangioma, hemangiosarcoma and mammary tumors. Vet Res Commun 2010, 34:153-160

24. De Mora F, Puigdemont A, Torres R: The role of mast cells in atopy: what can we learn from canine models? A thorough review of the biology of mast cells in canine and human systems. Br J Dermatol 2006, 155:1109-1123.

25. von Ruedorffer U, Fisch R, Peel J, Roosje P, Griot-Wenk M, Welle M: Flea bite hypersensitivity: new aspects on the involvement of mast cells. Vet J 2003, 165:149-156.

26. Brazís P, Queralt $M$, de Mora F, Ferrer L, Puigdemont A: Comparative study of histamine release from skin mast cells dispersed from atopic, ascarissensitive and healthy dogs. Vet Immunol Immunopathol 1998, 66:43-51.

27. Queralt M, Brazis P, Merlos M, Puigdemont A: Inhibitory effects of rupatadine on mast cell histamine release and skin wheal development induced by Ascaris suum in hypersensitive dogs. Drug Dev Res 1998 44:49-55.

28. Torres R, Grifols J, Fondevila D, de Mora F: Dermal exposure to Ag induces sensitization and inflammation, in addition to the immediate response, in the Ascaris suum-hypersensitive dog model of skin allergy [abstract]. Allergy 2003, 58(Suppl 74):262.

29. Brazís P, Barandica L, García F, Clough GF, Church MK, Puigdemont A: Dermal microdialysis in the dog: in vivo assessment of the effect of cyclosporin A on cutaneous histamine and prostaglandin D2 release. Vet Dermatol 2006, 17:169-174.

30. Torres R, Grifols J, Marco A, de Mora F: Sensitization of naive beagles by intradermal injection of an ascaris antigen: induction of a model of skin allergy. Immunopharmacol Immunotoxicol 2006, 28:697-702.

31. Olivry T, Dunston SM, Murphy KM, Moore PF: Characterization of the inflammatory infiltrate during lgE-mediated late phase reactions in the skin of normal and atopic dogs. Vet Dermatol 2001, 1:49-58.

32. Metz $M$, Siebenhaar F, Maurer M: Mast cell functions in the innate skin immune system. Immunobiology 2008, 213:251-260.

33. Cerrato $S$, Brazis $P$, Della Valle MF, Miolo A, Petrosino S, Di Marzo V, Puigdemont A: Effects of palmitoylethanolamide on the cutaneous allergic inflammatory response in Ascaris hypersensitive Beagle dogs. Vet J 2012, 191:377-382

34. Petrosino $S$, Cristino L, Karsak M, Gaffal E, Udea N, Tüting T, Bisogno T, De Filippis D, D'Amico A, Saturnino C, Orlando P, Zimmer A, luvone T, Di Marzo $\checkmark$ : Protective role of palmitoylethanolamide in contact allergic dermatitis. Allergy 2010, 65:698-711.

35. Pulvirenti N, Nasca MR, Micali G: Topical adelmidrol 2\% emulsion, a novel aliamide, in the treatment of mild atopic dermatitis in pediatric subjects: a pilot study. Acta Dermatovenerol Croat 2007, 15:80-83.

36. Rosenkrantz W: Practical applications of topical therapy for allergic, infectious, and seborrheic disorders. Clin Tech Small Anim Pract 2006, 21:106-116.

37. Olivry T, DeBoer DJ, Favrot C, Jackson HA, Mueller RS, Nuttall T, Prélaud P, International Task Force on Canine Atopic Dermatitis: Treatment of canine atopic dermatitis: 2010 clinical practice guidelines from the international task force on canine atopic dermatitis. Vet Dermatol 2010, 21:233-248 
38. Pucheu-Haston CM, Shuster D, Olivry T, Brianceau P, Lockwood P, McClanahan T, de Waal Malefyt R, Mattson JD, Hammerberg B: A canine model of cutaneous late-phase reactions: prednisolone inhibition of cellular and cytokine responses. Immunology 2006, 117:177-187.

39. Thomas RC, Logas D, Radosta L, Harrison J: Effects of a $1 \%$ hydrocortisone conditioner on haematological and biochemical parameters, adrenal function testing and cutaneous reactivity to histamine in normal and pruritic dogs. Vet Dermatol 1999, 10:109-116.

40. Ginel PJ, Garrido C, Lucena R: Effects of otic betamethasone on intradermal testing in normal dogs. Vet Dermatol 2007, 18:205-210.

41. Rivierre C, Dunston SM, Olivry T: Effects of a 1 per cent hydrocortisone conditioner on the prevention of immediate and late-phase reactions in canine skin. Vet Rec 2000, 147:739-742.

42. DeBoer DJ, Cooley AJ: Use of induced cutaneous immediate-type hypersensitivity reactions to evaluate anti-inflammatory effects of triamcinolone topical solution in three dogs. Vet Dermatol 2000, 11:25-33.

43. Temizel EM, Cihan H, Akhtardanesh B, Aytug N: Effect of prednisolone and cetirizine on D. farinae and histamine-induced wheal and flare response in healthy dogs. Tierarztl Prax Ausg K Kleintiere Heimtiere 2011, 39:25-30.

44. Bizikova P, Linder KE, Paps J, Olivry T: Effect of a novel topical diester glucocorticoid spray on immediate- and late-phase cutaneous allergic reactions in Maltese-beagle atopic dogs: a placebo-controlled study. Vet Dermatol 2010, 21:70-79.

45. Andersson M, Pipkorn U: Inhibition of the dermal immediate allergic reaction through prolonged treatment with topical glucocorticosteroids. J Allergy Clin Immunol 1987, 79:345-349.

46. Pipkorn U, Hammarlund A, Enerback L: Prolonged treatment with topical glucocorticoids results in an inhibition of the allergen-induced weal-andflare response and a reduction in skin mast cell numbers and histamine content. Clin Exp Allergy 1989, 19:19-25.

47. Merlos M, Giral M, Balsa D, Ferrando R, Queralt M, Puigdemont A, GarciaRafanell J, Forn J: Rupatadine, a new potent, orally active dual antagonist of histamine and platelet-activating factor (PAF). J Pharmacol Exp Ther 1997, 280:114-121.

48. Queralt M, Merlos M, Giral M, Puigdemont A: Dual effect of a new compound, rupatadine, on edema induced by platelet-activating factor and histamine in dogs: comparison with antihistamines and PAF antagonists. Drugs Dev Res 1996, 39:12-18.

49. Edwards AM, Stevens MT, Church MK: The effects of topical sodium cromoglicate on itch and flare in human skin induced by intradermal histamine: a randomised double-blind vehicle controlled intra-subject design trial. BMC Res Notes 2011, 4:47.

50. Brown JM, Wilson TM, Metcalfe DD: The mast cell and allergic diseases: role in pathogenesis and implications for therapy. Clin Exp Allergy 2008, 38:4-18.

51. Metz M, Maurer M: Innate immunity and allergy in the skin. Curr Opin Immunol 2009, 21:1-7.

52. Galli SJ, Tsai M: Mast cells in allergy and infection: Versatile effector and regulatory cells in innate and adaptive immunity. Eur J Immunol 2010, 40:1843-1851.

53. Galli SJ, Tsai M: IgE and mast cells in allergic disease. Nat Med 2012, 18:693-704.

54. Bischoff SC: Role of mast cells in allergic and non-allergic immune responses: comparison of human and murine data. Nat Rev Immunol 2007, 7:93-104.

55. Levi-Montalcini R, Skaper SD, Dal Toso R, Petrelli L, Leon A: Nerve growth factor: from neurotrophin to neurokine. Trends Neurosci 1996, 19:514-520.

56. Cole ZA, Clough GF, Church MK: Inhibition by glucocorticoids of the mast cell-dependent weal and flare response in human skin in vivo. Br J Pharmacol 2001, 132:286-292.

57. Romagnani S: Cytokines and chemoattractants in allergic inflammation. Mol Immunol 2002, 38:881-885.

58. Sawada J, Itakura A, Tanaka A, Furusaka T, Matsuda H: Nerve growth factor functions as a chemoattractant for mast cells through both mitogenactivated protein kinase and phosphatidylinositol 3-kinase signaling pathways. Blood 2000, 95:2052-2058.

59. Kawamoto K, Aoki J, Tanaka A, Itakura A, Hosono H, Arai H, Kiso Y, Matsuda $\mathrm{H}$ : Nerve growth factor activates mast cells through the collaborative interaction with lysophosphatidylserine expressed on the membrane surface of activated platelets. $J$ Immunol 2002, 168:6412-6419.
60. Sugawara K, Biró T, Tsuruta D, Tóth Bl, Kromminga A, Zákány N, Zimmer A, Funk W, Gibbs BF, Zimmer A, Paus R: Endocannabinoids limit excessive mast cell maturation and activation in human skin. J Allergy Clin Immunol 2012, 129:726-738.

61. Bradshaw HB, Walker JM: The expanding field of cannabimimetic and related lipid mediators. Br J Pharmacol 2005, 144:459-465.

62. De Petrocellis L, Di Marzo V: Non-CB(1), Non-CB(2) Receptors for Endocannabinoids, Plant Cannabinoids, and Synthetic Cannabimimetics: Focus on G-protein-coupled Receptors and Transient Receptor Potential Channels. J Neuroimmune Pharmacol 2010, 5:103-121.

63. Campora L, Miragliotta V, Ricci E, Cristino L, Di Marzo V, Albanese F, Della Valle MF, Abramo F: Cannabinoid receptor type 1 and 2 expression in the skin of healthy dogs and dogs with atopic dermatitis. Am J Vet Res 2012, 73:988-995.

64. Biro T, Toth Bl, Hasko G, Paus R, Pacher P: The endocannabinoid system of the skin in health and disease: novel perspectives and therapeutic opportunities. Trends Pharmacol Sci 2009, 30:411-420.

doi:10.1186/1746-6148-8-230

Cite this article as: Cerrato et al:: Inhibitory effect of topical Adelmidrol on antigen-induced skin wheal and mast cell behavior in a canine model of allergic dermatitis. BMC Veterinary Research 2012 8:230.

\section{Submit your next manuscript to BioMed Central and take full advantage of:}

- Convenient online submission

- Thorough peer review

- No space constraints or color figure charges

- Immediate publication on acceptance

- Inclusion in PubMed, CAS, Scopus and Google Scholar

- Research which is freely available for redistribution 